\title{
Infective endocarditis of composite aortic valve grafts
}

\author{
Carlo Olevano ${ }^{1}$, Pietro Malvindi ${ }^{2}$, Suvitesh Luthra ${ }^{2}$, and Sunil Ohri ${ }^{3}$ \\ ${ }^{1}$ Southampton General Hospital \\ ${ }^{2}$ University Hospital Southampton NHS Foundation Trust \\ ${ }^{3}$ Southampton University Hospitals
}

December 1, 2020

\begin{abstract}
Background The Infection of aortic valve graft conduit is still burdened by notable morbidity and mortality. Medical and surgical strategies play a crucial role in patient outcome and vary depending on infection extend into adjacent cardiac structures, systemic spread and micro-organism involved. Methods In this retrospective study, we report our experience in the management of thirty consecutive patients admitted to our centre with composite aortic valve graft infection during the period 2008-2018. We review the early and mid-term outcomes of patients who underwent a reoperation or received a conservative medical treatment. Results Twenty patients underwent redo surgery with an early mortality of $10 \%$ and a survival of $83 \%$ at 7 -year follow-up. Ten patients were treated medically and experienced an early mortality of $30 \%$ and a mid-term survival of $33 \%$. Conclusion A surgical reoperation, despite a non-negligible perioperative risk, is the only radical treatment able to provide a good survival also in patients with complicated infective endocarditis.
\end{abstract}

Title: Infective endocarditis of composite aortic valve grafts

Running head: management of Bentall infection

Carlo Olevano MD, Pietro Giorgio Malvindi MD, PhD, Suvitesh Luthra MD, Sunil Ohri MD PhD.

Wessex Cardiothoracic Centre, University Hospital Southampton, Southampton-UK

Abstract word count: 157 Word count: 2569

Corresponding author:

PG Malvindi

Wessex Cardiothoracic Centre

University Hospital Southampton

Tremona Road SO16 6YD, Southampton-UK

Tel:0044(0)2380777222 e-mail: pg.malvindi@hotmail.com

Data availability statement: The data that support the findings of this study are available from the corresponding author, Pietro Giorgio Malvindi M.D, upon reasonable request.

Funding statement: none

Conflict of interest: none.

Author's contribution

Olevano Carlo: Concept/design, drafting article, data collection, writing 
Pietro Giorgio Malvindi: Concept/design, statistics, data analysis/interpretation, writing

Suvitesh Luthra: Data collection, data interpretation, drafting article

Sunil Ohri: Critical revision of article, drafting article, approval of article

\section{Abstract}

\section{Background}

The Infection of aortic valve graft conduit is still burdened by notable morbidity and mortality. Medical and surgical strategies play a crucial role in patient outcome and vary depending on infection extend into adjacent cardiac structures, systemic spread and micro-organism involved.

\section{Methods}

In this retrospective study, we report our experience in the management of thirty consecutive patients admitted to our centre with composite aortic valve graft infection during the period 2008-2018. We review the early and mid-term outcomes of patients who underwent a reoperation or received a conservative medical treatment.

\section{Results}

Twenty patients underwent redo surgery with an early mortality of $10 \%$ and a survival of $83 \%$ at 7 -year follow-up. Ten patients were treated medically and experienced an early mortality of $30 \%$ and a mid-term survival of $33 \%$.

\section{Conclusion}

A surgical reoperation, despite a non-negligible perioperative risk, is the only radical treatment able to provide a good survival also in patients with complicated infective endocarditis.

Keywords: endocarditis, aortic valve, aortic root, reoperation

\section{Introduction}

Prosthetic valve endocarditis is not uncommon and accounts for about $30 \%$ of all the cases of infective endocarditis $(1,2)$. Its incidence after aortic valve replacement is estimated at $0.57 \%$ per person-year (3), and it is often associated with systemic and local cardiovascular complications. Surgical correction is usually indicated in these cases, but a reoperation is generally performed in only half of the patients (4-6). Surgical treatment carries high in-hospital mortality rate $(7,8)$ and this is particularly evident in patients who had undergone Bentall procedure $(9,10,11)$. On the other hand, medical therapy has been associated with a worse early outcome in patients with infective endocarditis who presented a theoretical indication for surgery $(4,12)$. The aim of our study is to review our results in the treatment of patients who were admitted with infective endocarditis of a composite aortic valve graft conduit after a Bentall procedure.

\section{Materials and Methods}

\section{Population}

The internal database of Wessex Cardiothoracic Centre at UHS was interrogated to find patients who were admitted with aortic valve prosthesis infective endocarditis during the period January 2008 - December 2018. Thirty patients who fulfilled the criteria of definite acute composite aortic valve graft endocarditis were included in the study.

\section{Study design and data collection}

This study is a retrospective outcome evaluation from institutional records with prospective data entry. Follow-up was completed by review of the online database system and patient's records. This study was registered in our institution as a service review, therefore ethical approval and informed consent were not deemed necessary. 


\section{Definitions}

Infective endocarditis was defined according to the modified Duke criteria (13) and a progressive extensive use of other imaging modalities (14). Anatomical and echocardiographic definitions align with ESC guidelines terminology (14). Surgical indications were based on recommendations of the most recent guidelines (14)(15). Anaemia and thrombocytopenia were graded according to WHO and NHLBI definitions.

\section{Medical management and surgical techniques}

All the patients admitted during the study period were evaluated and managed by a multidisciplinary team involving the figures of cardiologists, cardiac surgeons, intensivists and microbiologists. Further support when needed was obtained by cardiothoracic radiologists, vascular surgeons, neurologists, neurosurgeons and general surgeons. Antibiotic therapy was based on results of blood/specimen cultures or empirical therapy was provided according to guidelines (14); usually the treatment was maintained for 6 weeks. Surgery was always performed during the index hospitalisation. Timing of surgery varied according to the clinical scenario, anatomical findings and complications. A large ischaemic area or the presence of brain haemorrhage led to a delayed operation (as recommended at least 4 weeks) in case of stable haemodynamic and low risk of recurrent embolism.

All the operations were performed through a redo sternotomy. Radical debridement of all infective tissue and removal of necrotic tissue and prosthetic material were performed. Tissue and prosthetic specimens were always sent for culture and microbiologist evaluation. A new aortic prosthesis was then implanted, associated procedures were performed based on the extension of the infective process and the involvement of other cardiac structures.

Follow-up assessment was arranged at our outpatient clinic.

\section{Statistical analysis}

Continuous data are presented as mean \pm standard deviation or median [range], and categorical variables are given as counts and percentages. Survival rates were calculated using the Kaplan-Meier method. Statistical analyses were performed using the Stat-View Statistical Software Package 5.0 (SAS Institute, Inc., Cary, NC, USA), NCSS 2001 (Number Cruncher Statistical System, Kaysville, Utah).

\section{Results}

\section{Preoperative characteristics}

Twenty patients underwent a redo aortic procedure (66\% of the entire population). The remaining ten patients had conservative treatment which was proposed based on sepsis control in absence of heart failure and local complications in six patients, haemorrhagic cerebral stroke in 1 patients, ischaemic cerebral stroke in 1 case, bilateral pneumonia in 1 patient, high surgical risk due to multiple comorbidities in a 82-year old patient.

Table 1 details about preoperative characteristics and presentation of the two groups of patients. Previous procedures details are shown in Table 2.

At the reoperation, presence of vegetations was confirmed in 10 patients, in 14 cases there was a periannular abscess and 6 patients presented detachment of the aortic conduit from the left ventricle outflow tract. In patients who had medical management vegetations were described in 7 cases (70\%) and periannular abscess in 3 cases (30\%). None of the patients who underwent conservative treatment presented aorto-ventricular discontinuity at the admission.

Details about blood and tissue cultures results for the two groups are shown in Table 3.

\section{Surgical procedures}

Patients were reoperated after a median interval time of 12 days since the diagnosis and 7 days since the admission at our centre. 
Logistic EuroSCORE was $26 \% \pm 22 \%$. Redo aortic root replacement was performed in all the cases, associated procedures were necessary in 8 cases (patch annular repair in 6 patients, tricuspid valve repair in 1 patient, CABG in 2 cases, arch replacement in one patient).

\section{Survival}

In the surgical group two patients died before discharge for an overall in-hospital mortality of $10 \%$; causes of death were uncontrollable bleeding and multi-organ failure due to sepsis. The overall survival at 1-year and 7 -year follow up was $90 \%$ and $83 \%$, respectively.

Three patients who underwent medical management were not discharged from hospital (30\% mortality). One of them experienced a sudden death on day 17, one patient had a new cerebral embolism with brain haemorrhage and died 15 days after the admission, in one case there was a sudden deterioration with development of multiple organ failure due to combined sepsis and heart failure and death on day 11 since the admission.

The three patients who presented with a periannular abscess and underwent medical treatment died in the first 4 months since diagnosis. Furthermore, two patients in the medical group, who initially presented without local complications, developed a periannular abscess and rupture of the aorto-ventricular junction. In one case, there was a rapid expansion of the infective process despite an ongoing targeted antibiotic therapy, the patient ultimately died at 40 days since the diagnosis (Videos 1 and 2). The other patient had a relapse of infective endocarditis after 5 years and developed aorto-ventricular discontinuity with systolic graft collapse and severe mitral regurgitation (Video 3). Table 4 details about early and late course of patients who had lone medical treatment.

For patients who did not undergo a cardiac reoperation, the overall survival at 1-year and 7-year was $50 \%$ and $33 \%$, respectively.

\section{Discussion}

Endocarditis after composite valve graft root replacement (Bentall procedure) is not uncommon (16)(17) and is often associated with periannular abscess, disruption of aortic-ventricular junction and aortic false aneurysm (18-20). Redo root surgery is warranted in these cases and may poses difficulties in chest re-entry, in providing an adequate myocardial protection and handling of frail and infected tissue $(21,22)$. These patients can further present severe medical issues with ongoing heart failure and a poor controlled septic status, which account for a high perioperative mortality rate (9). Despite these technical and medical challenges, previous experiences reported good outcomes after reoperation for Bentall infection $(9,10,11,21,22)$ and our results, early mortality of $10 \%$ and acceptable survival at 7 -year follow-up, are in keeping with these findings.

Two large multi-institutional registries have recently shown that failure to undertake an operation in patients with infective endocarditis and presenting an indication for surgical treatment is a risk factor for early mortality $(4,23)$. On the contrary, a conservative approach seemed providing an acceptable survival especially in patients who did not have local complications, such as abscess, fistula or false aneurysm. These findings were retrieved from mixed populations, including native and prosthetic valve endocarditis, and few evidences exist regarding patients who had a previous root replacement with a valve graft conduit.

We found that a conservative treatment can be associated with a dismal early and mid-term survival also in patients who did not present at the admission with local infective complications and severe tissue disruption. In our series, the most common reason for a conservative treatment was the presence of stable haemodynamic, controlled sepsis and the absence of local infective complications. Among these six patients who had no urgent indication for a surgical procedure $(14,24)$, four did generally well and had a satisfactory survival, while two patients sustained a relapse of infective endocarditis with uncontrolled sepsis and heart failure.

Machelar et al. reported their experience in 8 patients with aortic valve graft conduit infection who were ultimately treated conservatively (25). Among them, one died due to cerebral haemorrhage after 6 weeks and one due to polymicrobial infection after 18 months. Another patient sustained a recurrent infection, 
and one was still on treatment. Four patients had complete remission during a follow-up time ranging from 30 to 68 months and, noteworthy, none of them had local infective complications at the admission. Similar results were found in our population, as we showed that patients with a stable clinical picture in absence of periannular abscess or aorto-ventricular disruption could be successfully managed with medical treatment in the acute setting. Alongside a less severe anatomical disruption, Staphylococcus aureus was not isolated, both in Machelar's and our experiences, in any of the patients who sustained a complete remission after lone antibiotic treatment.

\section{Conclusions}

Medical treatment provided to be a reasonable option in uncomplicated cases of Bentall infective endocarditis, although, relapse of infection of the aortic conduit is not uncommon during early and mid-term follow-up. A close clinical and imaging follow-up is necessary in these patients in order to rule out any subtle recurrence or development of complications following a multimodality imaging approach in case of inconclusive or suspicious transthoracic or transoesophageal echocardiography $(14,25,26)$. A surgical reoperation represents the only definitive approach especially in complicated cases. Despite expected technical and medical difficulties and a non-negligible operative mortality, the benefits of redo surgery are stable with satisfactory outcomes at mid-term follow-up.

\section{References}

1 - Murdoch DR, Corey GR, Hoen B, et al. Clinical presentation, etiology, and outcome of infective endocarditis in the 21st century: the International Collaboration on Endocarditis-Prospective Cohort Study. Arch Intern Med 2009;169:463-73

2 - Wang A, Athan E, Pappas PA, et al. Contemporary clinical profile and outcome of prosthetic valve endocarditis. JAMA 2007;297:1354-61

3 - Glaser N, Jackson V, Holzmann MJ, et al. Prosthetic Valve Endocarditis After Surgical Aortic Valve Replacement. Circulation 2017;136:329-31

4 - Habib G, Erba PA, Iung B, Donal E, Cosyns B, Laroche C, Popescu BA, Prendergast B, Tornos P, Sadeghpour A, Oliver L, Vaskelyte JJ, Sow R, Axler O, Maggioni AP, Lancellotti P; EURO-ENDO Investigators. Clinical presentation, aetiology and outcome of infective endocarditis. Results of the ESC-EORP EURO-ENDO (European infective endocarditis) registry: a prospective cohort study. Eur Heart J. 2019 Oct 14;40(39):3222-3232

5 - Tornos P, Iung B, Permanyer-Miralda G, Baron G, Delahaye F, Gohlke-Bärwolf Ch, Butchart EG, Ravaud P, Vahanian A. Infective endocarditis in Europe: lessons from the Euro heart survey. Heart. 2005 May;91(5):571-5

6 - Pericart L, Fauchier L, Bourguignon T, Bernard L, Angoulvant D, Delahaye F, Babuty D, Bernard A. Long-Term Outcome and Valve Surgery for Infective Endocarditis in the Systematic Analysis of a Community Study. Ann Thorac Surg. 2016 Aug;102(2):496-504

7 - Manne MB, Shrestha NK, Lytle BW, Nowicki ER, Blackstone E, Gordon SM, Pettersson G, Fraser TG. Outcomes after surgical treatment of native and prosthetic valve infective endocarditis. Ann Thorac Surg. 2012 Feb;93(2):489-93

8 - Leontyev S, Davierwala PM, Krogh G, et al. Early and late outcomes of complex aortic root surgery in patients with aortic root abscesses. Eur J Cardiothorac Surg 2016;49:447-54

9 - Jassar AS, Desai ND, Kobrin D, Pochettino A, Vallabhajosyula P, Milewski RK, McCarthy F, Maniaci J, Szeto WY, Bavaria JE. Outcomes of aortic root replacement after previous aortic root replacement: the "true" redo root. Ann Thorac Surg. 2015 May;99(5):1601-8

10 - Esaki J, Leshnower BG, Binongo JN, Lasanajak Y, McPherson L, Thourani VH, Chen EP. Reoperative 
aortic root replacement: Outcome in a contemporary series. J Thorac Cardiovasc Surg. 2017 Sep;154(3):800808

11 - Garrido-Olivares L, Maganti M, Armstrong S, David TE. Clinical outcomes of aortic root replacement after previous aortic root replacement. J Thorac Cardiovasc Surg. 2013 Sep;146(3):611-5

12 - Mihos CG, Capoulade R, Yucel E, Picard MH, Santana O. Surgical Versus Medical Therapy for Prosthetic Valve Endocarditis: A Meta-Analysis of 32 Studies. Ann Thorac Surg. 2017 Mar;103(3):991-1004

13 - Li JS, Sexton DJ, Mick N, Nettles R, Fowler VG Jr, Ryan T, Bashore T, Corey GR. Proposed modifications to the Duke criteria for the diagnosis of infective endocarditis. Clin Infect Dis. 2000 Apr;30(4):633-8

14 - Habib G, Lancellotti P, Antunes MJ, Bongiorni MG, Casalta JP, Del Zotti F, Dulgheru R, El Khoury G, Erba PA, Iung B, Miro JM, Mulder BJ, Plonska-Gosciniak E, Price S, Roos-Hesselink J, Snygg-Martin U, Thuny F, Tornos Mas P, Vilacosta I, Zamorano JL; ESC Scientific Document Group. 2015 ESC Guidelines for the management of infective endocarditis: The Task Force for the Management of Infective Endocarditis of the European Society of Cardiology (ESC). Endorsed by: European Association for Cardio-Thoracic Surgery (EACTS), the European Association of Nuclear Medicine (EANM). Eur Heart J. 2015 Nov 21;36(44):30753128

15 - Nishimura RA, Otto CM, Bonow RO, et al. 2017 AHA/ACC Focused Update of the 2014 AHA/ACC Guideline for the Management of Patients With Valvular Heart Disease: A Report of the American College of Cardiology/American Heart Association Task Force on Clinical Practice Guidelines. J Am Coll Cardiol 2017;70:252-89

16 - Flynn CD, Tian DH, Wilson-Smith A, David T, Matalanis G, Misfeld M, Mastrobuoni S, El Khoury G, Yan TD. Systematic review and meta-analysis of surgical outcomes in Marfan patients undergoing aortic root surgery by composite-valve graft or valve sparing root replacement. Ann Cardiothorac Surg. 2017 Nov;6(6):570-581

17 - Mookhoek A, Korteland NM, Arabkhani B, Di Centa I, Lansac E, Bekkers JA, Bogers AJ, Takkenberg JJ. Bentall Procedure: A Systematic Review and Meta-Analysis. Ann Thorac Surg. 2016 May;101(5):1684-9

18 - Malvindi PG, Mikus E, Caprili L, Santarpino G, Margari V, Calvi S, Nasso G, Gregorini R, Carbone C, Albertini A, Speziale G, Paparella D. Aortic valve endocarditis complicated by proximal false aneurysm. Ann Cardiothorac Surg. 2019 Nov;8(6):667-674

19 - Graupner C, Vilacosta I, San Roman JA, et al. Periannular extension of infective endocarditis. J Am Coll Cardiol 2002;39:1204-11

20 - Baumgartner FJ, Omari BO, Robertson JM, et al. Annular abscesses in surgical endocarditis: anatomic, clinical, and operative features. Ann Thorac Surg 2000;70:442-7

21 - Malvindi PG, van Putte BP, Heijmen RH, Schepens MA, Morshuis WJ. Reoperations on the aortic root: experience in 46 patients. Ann Thorac Surg. 2010 Jan;89(1):81-6

22 - Malvindi PG, van Putte BP, Heijmen RH, Schepens MA, Morshuis WJ. Reoperations for aortic false aneurysms after cardiac surgery. Ann Thorac Surg. 2010 Nov;90(5):1437-43

23 - Lalani T, Chu VH, Park LP, Cecchi E, Corey GR, Durante-Mangoni E, Fowler VG Jr, Gordon D, Grossi P, Hannan M, Hoen B, Muñoz P, Rizk H, Kanj SS, Selton-Suty C, Sexton DJ, Spelman D, Ravasio V, Tripodi MF, Wang A; International Collaboration on Endocarditis-Prospective Cohort Study Investigators. In-hospital and 1-year mortality in patients undergoing early surgery for prosthetic valve endocarditis. JAMA Intern Med. 2013 Sep 9;173(16):1495-504

24 - Nishimura RA, Otto CM, Bonow RO, et al. 2017 AHA/ACC Focused Update of the 2014 AHA/ACC Guideline for the Management of Patients With Valvular Heart Disease: A Report of the American College 
of Cardiology/American Heart Association Task Force on Clinical Practice Guidelines. J Am Coll Cardiol 2017;70:252-89

25 - Machelart I, Greib C, Wirth G, Camou F, Issa N, Viallard JF, Pellegrin JL, Lazaro E. Graft infection after a Bentall procedure: A case series and systematic review of the literature. Diagn Microbiol Infect Dis. 2017 Jun;88(2):158-162

26 - Heuzé C, Lepage L, Loubet P, Duval X, Cimadevilla C, Verdonk C, Hyafil F, Rouzet F, Ou P, Nataf P, Vahanian A, Messika-Zeitoun D. Infective Endocarditis After Bentall Surgery: Usefulness of New Imaging Modalities and Outcomes. JACC Cardiovasc Imaging. 2018 Oct;11(10):1535-1537

\section{Videos}

Video 1. TTE showed normal function of aortic valve prosthesis and absence of abscess or false aneurysm in a patient with positive blood culture for Coagulase negative Staphylococcus and presence of small vegetations $(<1 \mathrm{~cm})$. Patient 8 in Table 4.

Video 2. After 1 month, despite targeted antibiotic therapy, patient deteriorated and TOE showed a false aneurysm (cavity with systolic pulse around the valve graft conduit) arising from the aorto-mitral continuity. Patient 8 in Table 4.

Video 3. TOE showed disruption of the aorto-mitral continuity with systolic graft collapse. Patient 2 in Table 4 .

Table 1. Patients' characteristics and clinical presentation

\begin{tabular}{lll}
\hline & Surgical treatment & Medical treatment \\
\hline Variables & Number (\%) or Mean \pm SD or & Number (\%) or Mean \pm SD or \\
& Median [range] & Median [range] \\
Patients & 20 & 10 \\
Age (years) & $52 \pm 16$ & $61 \pm 13$ \\
Gender M/F & $19 / 1$ & $9 / 1$ \\
Diabetes Mellitus & 0 & 0 \\
Previous Cerebral Stroke & $4(20 \%)$ & 0 \\
Haemodialysis & $2(10 \%)$ & 0 \\
History of cancer & $1(5 \%)$ & 0 \\
Liver disease & 0 & 0 \\
IDU & $3(15 \%)$ & 0 \\
Alcohol addiction & 0 & 0 \\
Immunosuppressive therapy & $1(5 \%)$ & $1(10 \%)$ \\
Previous infective endocarditis & $8(40 \%)$ & $2(20 \%)$ \\
Atrial fibrillation & $2(10 \%)$ & $2(20 \%)$ \\
Permanent pacemaker & 0 & $2(20 \%)$ \\
NYHA III-IV & $8(40 \%)$ & $1(10 \%)$ \\
Fever & $14(70 \%)$ & $9(90 \%)$ \\
Asthenia & $16(80 \%)$ & $6(60 \%)$ \\
Embolism Cerebral Abdomen & $3(15 \%) 2(10 \%) 2(10 \%) 01$ & $2(20 \%) 2(20 \%) 0 ~ 1(10 \%)$ \\
Peripheral Multi & $(5 \%)$ & $1(10 \%)$ \\
Preoperative inotropes & $2(10 \%)$ & $1(10 \%)$ \\
Creatinine>200 mmol/L & $1(5 \%)$ & 0 \\
LVEF (\%) 30 - 50 & $4(20 \%)$ & $1(10 \%)$ \\
PAPs > 30 mmHg & $6(30 \%)$ & $1(10 \%)$ \\
Anaemia Mild Moderate Severe & 1370 & 540 \\
Thrombocytopenia Mild & 11 & 00 \\
Moderate & & \\
& &
\end{tabular}




\begin{tabular}{lll}
\hline & Surgical treatment & Medical treatment \\
\hline $\mathrm{CRP}(\mathrm{mg} / \mathrm{L})$ & $108[2-334]$ & $122[10-266]$ \\
\hline
\end{tabular}

Table 2. Previous operation(s)

\begin{tabular}{|c|c|c|}
\hline & Surgical treatment & Medical treatment \\
\hline Variables & Number $(\%)$ or Median [range] & Number (\%) or Median [range] \\
\hline Aortic valve + root replacement & $17(85 \%)$ & $5(50 \%)$ \\
\hline $\begin{array}{l}\text { Aortic valve }+ \text { root replacement } \\
+ \text { tricuspid valve repair }\end{array}$ & $1(5 \%)$ & 0 \\
\hline $\begin{array}{l}\text { Aortic valve }+ \text { root }+ \text { mitral } \\
\text { valve replacement }\end{array}$ & 0 & $1(10 \%)$ \\
\hline $\begin{array}{l}\text { Aortic valve }+ \text { root }+ \text { mitral } \\
\text { valve replacement }+ \text { tricuspid } \\
\text { valve repair }\end{array}$ & 0 & $1(10 \%)$ \\
\hline Aortic valve + root + CABG & $1(5 \%)$ & 0 \\
\hline $\begin{array}{l}\text { Aortic valve }+ \text { root }+ \\
\text { ascending aorta }\end{array}$ & $1(5 \%)$ & $3(30 \%)$ \\
\hline Biological prosthesis & $8(40 \%)$ & $5(50 \%$ \\
\hline Mechanical prosthesis & $12(60 \%)$ & $5(50 \%)$ \\
\hline $\begin{array}{l}\text { Number of previous cardiac } \\
\text { operation(s) } 12\end{array}$ & 164 & 73 \\
\hline $\begin{array}{l}\text { Interval time between index } \\
\text { treatment and last operation } \\
\text { (months) }\end{array}$ & $71[2-267]$ & $35[3-117]$ \\
\hline
\end{tabular}

Table 3. Blood and surgical specimens culture results

Variables

Positive blood cultures Streptococcus spp. Enterococcus Candida St. aureus Coagulase negative Staphylococci Other Gram Positive tissue culture Enterococcus Candida St. aureus

Table 4. Details of patients who underwent medical management

\begin{tabular}{|c|c|c|c|c|c|c|c|}
\hline & Age & Gender & $\begin{array}{l}\mathrm{CRP} \text { at the } \\
\text { admission } \\
(\mathrm{mg} / \mathrm{L})\end{array}$ & Vegetations & $\begin{array}{l}\text { Abscess/ } \\
\text { False } \\
\text { aneurysm }\end{array}$ & $\begin{array}{l}\text { Isolated Status at } \\
\text { microorganismdischarge }\end{array}$ & Follow- \\
\hline $\begin{array}{l}\text { Patient } \\
1\end{array}$ & 37 & Female & 184 & $<1 \mathrm{~cm}$ & No & $\begin{array}{l}\text { Strep } \\
\text { group A }\end{array}$ & $\begin{array}{l}\text { Alive a } \\
135 \\
\text { months }\end{array}$ \\
\hline
\end{tabular}




\begin{tabular}{|c|c|c|c|c|c|c|c|c|}
\hline & Age & Gender & $\begin{array}{l}\mathrm{CRP} \text { at the } \\
\text { admission } \\
(\mathrm{mg} / \mathrm{L})\end{array}$ & Vegetations & $\begin{array}{l}\text { Abscess/ } \\
\text { False } \\
\text { aneurysm }\end{array}$ & $\begin{array}{l}\text { Isolated } \\
\text { microorganism }\end{array}$ & $\begin{array}{l}\text { Status at } \\
\text { ndischarge }\end{array}$ & Follow- \\
\hline $\begin{array}{l}\text { Patient } \\
2\end{array}$ & 59 & Male & 55 & No & No & $\begin{array}{l}\text { Strep } \\
\text { group A }\end{array}$ & Alive & $\begin{array}{l}\text { Died at } \\
69 \\
\text { months } \\
\text { relapse } \\
\text { with } \\
\text { heart } \\
\text { failure }\end{array}$ \\
\hline $\begin{array}{l}\text { Patient } \\
3\end{array}$ & 53 & Male & 31 & $>1 \mathrm{~cm}$ & No & $\begin{array}{l}\text { Strep } \\
\text { bovis }\end{array}$ & Alive & $\begin{array}{l}\text { Died at } \\
98 \\
\text { months } \\
\text { not } \\
\text { related } \\
\text { to } \\
\text { infectio }\end{array}$ \\
\hline $\begin{array}{l}\text { Patient } \\
4\end{array}$ & 82 & Male & 266 & No & Abscess & $\begin{array}{l}\text { Staph } \\
\text { aureus }\end{array}$ & Dead & \\
\hline $\begin{array}{l}\text { Patient } \\
5\end{array}$ & 71 & Male & 119 & $<1 \mathrm{~cm}$ & Abscess & - & Alive & $\begin{array}{l}\text { Died at } \\
4 \\
\text { months } \\
\text { lack of } \\
\text { recover }\end{array}$ \\
\hline $\begin{array}{l}\text { Patient } \\
6\end{array}$ & 72 & Male & 10 & $<1 \mathrm{~cm}$ & No & - & Alive & $\begin{array}{l}\text { Alive a } \\
58 \\
\text { months }\end{array}$ \\
\hline $\begin{array}{l}\text { Patient } \\
7\end{array}$ & 54 & Male & 84 & $>1 \mathrm{~cm}$ & No & Gram + & Alive & $\begin{array}{l}\text { Alive a } \\
59 \\
\text { months }\end{array}$ \\
\hline $\begin{array}{l}\text { Patient } \\
8\end{array}$ & 68 & Male & 237 & $<1 \mathrm{~cm}$ & No & $\begin{array}{l}\text { Coag } \\
\text { neg } \\
\text { Staph }\end{array}$ & Alive & $\begin{array}{l}\text { Died at } \\
1 \\
\text { month, } \\
\text { relapse } \\
\text { with } \\
\text { heart } \\
\text { failure } \\
\text { and } \\
\text { sepsis }\end{array}$ \\
\hline $\begin{array}{l}\text { Patient } \\
9\end{array}$ & 51 & Male & 125 & No & Abscess & $\begin{array}{l}\text { Staph } \\
\text { aureus }\end{array}$ & Dead & \\
\hline $\begin{array}{l}\text { Patient } \\
10\end{array}$ & 70 & Male & 128 & $>1 \mathrm{~cm}$ & No & Trichosporon & Dead & \\
\hline
\end{tabular}

